\title{
Karakteristik Pelaku dan Perilaku Perjalanan Penumpang Bus Trans Koetaradja
}

\author{
Hitapriya Suprayitno ${ }^{1, *}$, Muhammad Ryansyah ${ }^{1, *}$ \\ Departemen Teknik Sipil, Institut Teknologi Sepuluh Nopember, Surabaya ${ }^{1}$ \\ Koresponden*, Email: suprayitno.hita@gmail.com
}

\begin{tabular}{|c|c|}
\hline Info Artikel & Abstract \\
\hline Diajukan 24 Mei 2018 & Trans Koetaradja Master Plan is being implemented step by step. The Corridor 1: Keudah - \\
\hline Diperbaiki 04 Oktober 2018 & Darulsalam will be operated, therefore a passenger demand prediction need to be calculated. \\
\hline Disetujui 10 Oktober 2018 & $\begin{array}{l}\text { This calculation needs data on characteristics of the trip maker and travel behavior. The data } \\
\text { were gotten from the survey done upon Koridor 1: Keudah - Darulsalam. The trip maker } \\
\text { gender characteristics are dominated by the female trip maker, the profession characteristics } \\
\text { are dominated by worker and student. The travel behavior characteristics, in term of trip } \\
\text { purpose, are dominated by working and academics trips; in terms of mode utilisations before } \\
\text { changing to the bus are dominated by microbus public transport and motorcycle. Access trip }\end{array}$ \\
\hline $\begin{array}{l}\text { Keywords: trip maker characteristics, } \\
\text { travel behaviour characteristics, bus } \\
\text { passenger, Trans Koetaradja. }\end{array}$ & $\begin{array}{l}\text { distances are around 0-1.5 } \mathrm{km} \text {, by walking. Access trip distances are around } 0-1 \mathrm{~km} \text {, mostly by } \\
\text { walking. The number of passengers in the morning peak-hour is very view of about } 10 \\
\text { passengers only, while in the noon peak hour is normal of around } 40-50 \text { passengers. }\end{array}$ \\
\hline
\end{tabular}

Abstrak

Penerapan Rencana Induk Bus Trans Koetaradja sedang dilaksanakan secara bertahap. Koridor 1: Keudah-Darulsalam akan dioperasikan, oleh karena itu dibutuhkan perhitungan prakiraan penumpang potensial. Perhitungan ini membutuhkan data karakteristik pelaku dan perilaku perjalanan. Data karakteristik didapatkan dari survei di Koridor 1: Keudah-Darulsalam. Pelaku perjalanan dalam hal komposisi jenis kelamin didominasi oleh wanita, dalam hal komposisi profesi didominasi oleh pegawai, mahasiswa dan pelajar. Karakteristik perilaku perjalanan, dalam hal komposisi maksud perjalanan didominasi oleh perjalanan bekerja, perjalanan kuliah dan perjalanan sekolah; dalam hal penggunaan moda sebelum beralih didominasi oleh angkot mikrobis dan sepeda motor. Karakteristik perjalanan hubung-ke, dalam hal jarak perjalanan berada pada kisaran 0-1,5 km dengan moda jalan kaki. Karakteristik perjalanan hubung dari, dalam hal jarak perjalanan berada pada kisaran 0-1 km dengan moda jalan kaki. Jumlah penumpang pada jam puncak pagi sangat sedikit pada kisaran 10 orang, sedangkan pada jam puncak siang

Kata kunci: karakteristik pelaku perjalanan, karakteristik perilaku perjalanan, penumpang bus kota, Trans Koetaradja. cukup normal pada kisaran 40-50 orang.

\section{Pendahuluan}

Rencana induk jaringan Bis Trans Koetaradja telah selesai direncanakan. Jaringan Bis Trans Koetaradja direncanakan mengandung 6 koridor: Koridor 1: KeudahDarulsalam, Koridor 2: Pelabuhan Ulele-Keudah-Bandara Iskandar Muda, Koridor 3: Keudah-Mata Ie, Koridor 4: Keudah-Lhok Nga, Koridor 5: Ulee Kareng-Terminal Bis A dan Koridor 6: Terminal Bis A-Syah Kuala. Pada saat ini April 2018, Koridor 1 dan Koridor 2 telah dioperasikan [1].

Sistem operasional layanan bis kota ini harus direncanakan dengan baik agar bisa menjalankan fungsinya sebagai angkutan perkotaan modern bagi wilayah perkotaan Banda Aceh. Salah satu komponen perencanaan tersebut adalah penentuan ukuran armada bus yang akan dioperasikan pada suatu koridor [2],[3],[4]. Koridor 4 direncanakan akan segera dioperasikan, dalam waktu beberapa bulan kedepan. Untuk itu diperlukan perhitungan prediksi jumlah penumpang potensial.
Perhitungan prediksi jumlah penumpang potensial merupakan bagian dari pemodelan transportasi. Perhitungan ini merupakan suatu pemodelan permintaan transportasi pada kawasan yang sangat terbatas dan berupa sebuah kawasan jalur. Dua teknik pemodelan sudah pernah dipikirkan dan dicoba adalah model langsung dan model konvensional khusus [2],[3],[4],[5],[6].

Untuk melakukan perhitungan tersebut diperlukan data karakteristik perilaku perjalanan yang berupa data tentang wilayah pengaruh perjalanan hubung ke, wilayah pengaruh perjalanan hubung dari, dan karakteristik moda sebelum [2], [3],[4].

Makalah ini menyampaikan data hasil survei tentang karakteristik pelaku perjalanan dan perilaku perjalanan untuk Bis Trans Koetaradja Koridor 1: Keudah - Darulsalam, pada jam puncak pagi dan jam puncak siang. 


\section{Metode}

Penelitian ini pada dasarnya merupakan pengumpulan data karakteristik pelaku dan perilaku perjalanan Bis Trans Koetaradja Koridor 1. Untuk itu, hal penting yang harus ditentukan ada tiga hal berikut ini: informasi yang harus dikumpulkan, cara mengumpulkan dan penentuan jumlah sampel.

Informasi yang harus dikumpulkan adalah data yang diperlukan bagi pemodelan. Pemodelan akan dilakukan berdasarkan data survei wawancara rumah tangga. Data untuk pemodelan dan data karakteristik terkait disampaikan pada Tabel 1. Data karakteristik ini akan dikumpulkan dengan cara survei wawancara di kendaraan dengan jumlah sampel minimum 30\%.

Tabel 1. Data pemodelan dan karakteristik perjalanan Bis Trans Koetaradja Koridor 1

\begin{tabular}{cll}
\hline No & Data bagi Pemodelan & Data Karakteristik Terkait \\
\hline 1 & Wilayah Pengaruh Ke Bis & Jarak Perjalanan Hubung Ke \\
2 & Moda Perjalanan Hubung Ke & Moda Perjalanan Hubung Ke \\
3 & Wilayah Pengaruh Dari Bis & Jarak Perjalanan Hubung Dari \\
4 & Moda Perjalanan Hubung Dari & Moda Perjalanan Hubung Dari \\
5 & Moda yang mungkin pindah & Moda Sebelum Menggunakan Bis Trans \\
6 & Kestabilan Nilai Data & Maksud Perjalanan \\
\hline
\end{tabular}

Untuk memudahkan analisis penelitian ini, beberapa istilah perlu dibakukan. Untuk itu perjalanan dengan menggunakan Bis Trans Koetaradja ini perlu dimodelkan sebagai sebuah jaringan. Perjalanan ini dibagi ke dalam 3 (tiga) tahap perjalanan, yakni: Perjalanan dengan menggunakan Moda Utama (PMU), yang didahului oleh Perjalanan Hubung Ke (PHK) dan diakhiri dengan Perjalanan Hubung Dari (PHD). Perpindahan dari PHK ke PMU dilakukan di Simpul Naik (SN), sedangkan perpindahan dari PMU ke PHD dilakukan di Simpul Turun (ST). Dalam kasus penelitian ini, perjalanan hubung bisa saja mengandung lebih dari 1 PHK dan 1 PHD. Ilustrasi model jaringan suatu perjalanan disampaikan seperti pada Gambar 1.

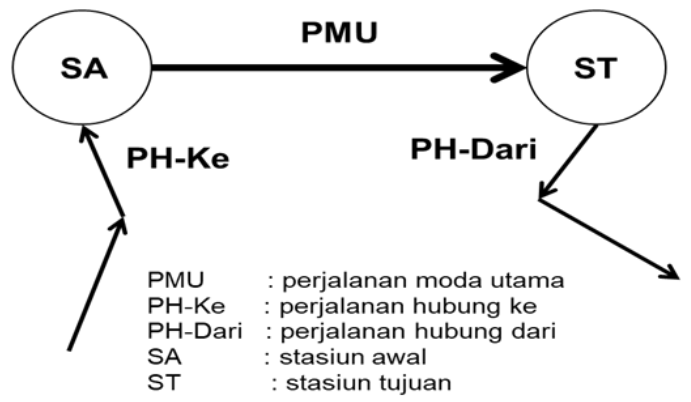

Gambar 1. Model jaringan suatu perjalanan dengan menggunakan moda utama

\section{Hasil dan Pembahasan}

Karakteristik perilaku perjalanan yang diamati dalam survei ini adalah maksud perjalanan, moda sebelum berpindah ke Bis Trans Koetaradja, perjalanan hubung ke Trans Koetaradja, jarak perjalanan dan moda perjalanan, perjalanan hubung dari Trans Koetaradja, jarak perjalanan dan moda perjalanan.

Survei sudah dilakukan pada jam puncak pagi dan jam puncak siang. Survei menangkap fenomena yang penting untuk dicatat. Volume penumpang pada jam puncak pagi hanya sekitar 10 penumpang per bis; sedangkan pada jam puncak siang mencapai sekitar 50 orang per bis. Hal ini berlawanan dengan sifat perjalanan orang di wilayah perkotaan, dimana volume perjalanan jam puncak pagi sangat tinggi dibanding yang lain.

\section{Karakteristik pada Jam Puncak Siang}

Karakteristik pelaku perjalanan untuk komposisi jenis kelamin atau gender terdiri dari wanita $86 \%$ dan laki-laki 15\%. Komposisi profesi didominasi oleh pegawai 55\% dan mahasiswa 35\%. Data karakterisitk disampaikan pada Tabel 2-3, serta Gambar 2-3.

Tabel 2. Komposisi jenis kelamin pelaku perjalanan pada jam puncak pagi

\begin{tabular}{ccccc}
\hline No & Gender & Jumlah & Prosentase & Komulatif \\
\hline 1 & Wanita & 17 & $85 \%$ & $85 \%$ \\
2 & Laki-Laki & 3 & $15 \%$ & $100 \%$ \\
\hline \multicolumn{5}{c}{$100 \%$} \\
\hline
\end{tabular}

\section{KomposisiJenis Kelamin Pelaku Perjalanan Jam Puncak Pagi}

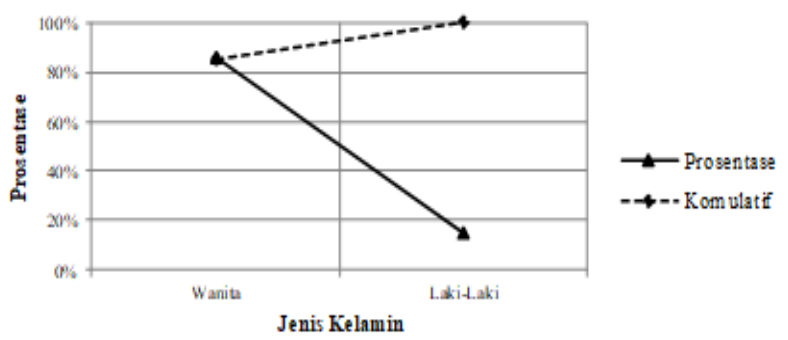

Gambar 2. Komposisi jenis kelamin pelaku perjalanan pada jam puncak pagi 
Tabel 3. Komposisi profesi pelaku perjalanan pada jam puncak pagi

\begin{tabular}{|c|c|c|c|c|}
\hline No & Profesi & Jumlah & Prosentase & Komulatif \\
\hline 1 & Pegawai & 11 & $55 \%$ & $55 \%$ \\
\hline 2 & Mahasiswa & 7 & $35 \%$ & $85 \%$ \\
\hline 3 & Ibu RT & 2 & $10 \%$ & $100 \%$ \\
\hline & & 20 & $100 \%$ & \\
\hline
\end{tabular}

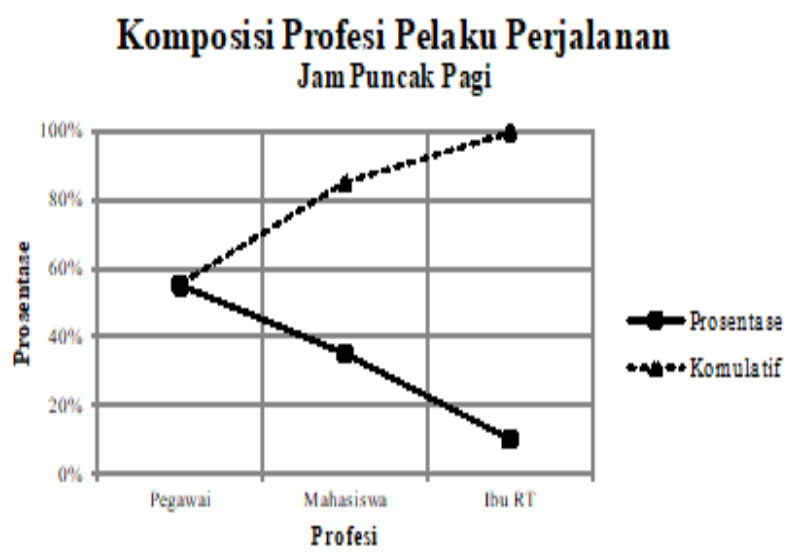

Gambar 3. Komposisi profesi pelaku perjalanan pada jam puncak pagi

Karakteristik perilaku dengan maksud perjalanan disominasi oleh perjalanan bekerja (55\%) dan perjalanan belanja (25\%). Moda sebelum beralih ke Bis Trans Koetaradja didominasi oleh moda mikrobis (80\%) dengan moda sepeda motor (20\%). Data karakterisitk disampaikan pada Tabel 4-5, serta Gambar 4-5.

Tabel 4. Komposisi maksud perjalanan pada jam puncak pagi

\begin{tabular}{|c|c|c|c|c|}
\hline $\mathrm{No}_{0}$ & Maksud & Jumlah & Prosentase & Komulatif \\
\hline 1 & Bekerja & 11 & $55 \%$ & $55 \%$ \\
\hline 2 & Belanja & 5 & $25 \%$ & $80 \%$ \\
\hline 3 & Kuliah & 4 & $20 \%$ & $100 \%$ \\
\hline & & 20 & $100 \%$ & \\
\hline
\end{tabular}

\section{Komposisi Maksud Perjalanan Jam Puncak Pagi}

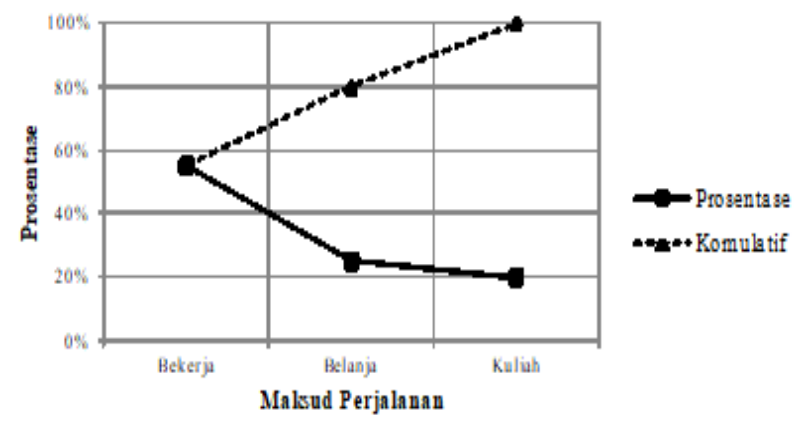

Gambar 4. Komposisi maksud perjalanan pada jam puncak pagi

Tabel 5. Komposisi penggunaan moda sebelum beralih pada jam puncak pagi

\begin{tabular}{ccccc}
\hline No & Moda & Jumlah & Prosentase & Komulatif \\
\hline 1 & Angkot & 16 & $80 \%$ & $80 \%$ \\
2 & Sepeda Motor & 4 & $20 \%$ & $100 \%$ \\
3 & Mobil & 0 & $0 \%$ & $100 \%$ \\
\hline \multicolumn{5}{c}{20} \\
\hline
\end{tabular}

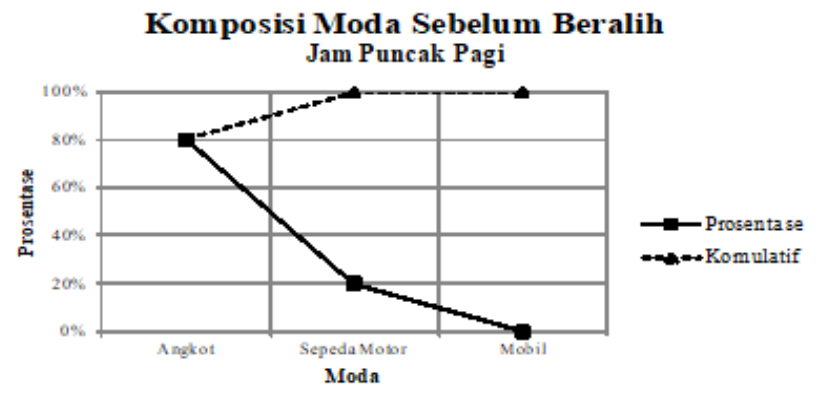

Gambar 5. Komposisi penggunaan moda sebelum beralih pada jam puncak pagi

Karakteristik perilaku perjalanan hubung ke Bis Trans Koetaradja terkait jarak perjalanan hubung didominasi oleh kisaran 0,0 - 1,5 km (90\%). Moda perjalanan hubung ke didominasi oleh pejalan kaki (90\%). Data karakteristik perjalanan hubung ke disampaikan pada Tabel 6-7, dan Gambar 6-7.

Tabel 6. Komposisi jarak perjalanan hubung ke pada jam puncak pagi

\begin{tabular}{ccccc}
\hline No & Jarak & Jumlah & Prosentase & Komulatif \\
\hline 1 & $0,0-0,5 \mathrm{~km}$ & 8 & $40 \%$ & $40 \%$ \\
2 & $0,5-1,0 \mathrm{~km}$ & 7 & $35 \%$ & $75 \%$ \\
3 & $1,0-1,5 \mathrm{~km}$ & 3 & $15 \%$ & $90 \%$ \\
4 & $1,5-2,0 \mathrm{~km}$ & 1 & $5 \%$ & $95 \%$ \\
5 & $2,0-3,0 \mathrm{~km}$ & 1 & $5 \%$ & $100 \%$ \\
\hline \multicolumn{5}{c}{} \\
\hline
\end{tabular}




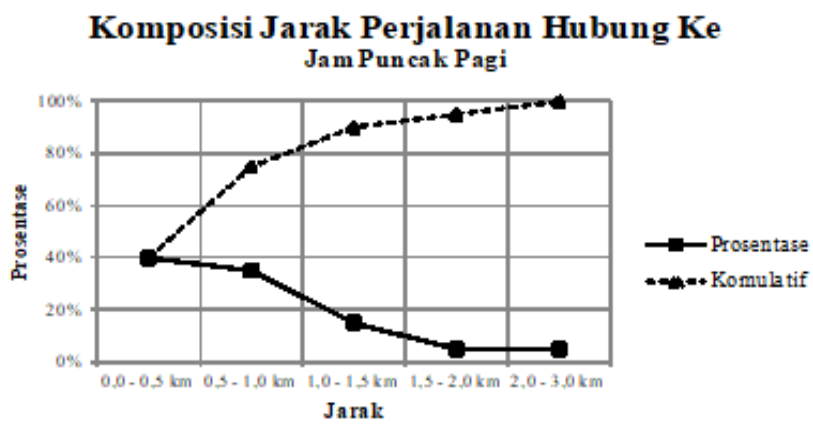

Gambar 6. Komposisi jarak perjalanan hubung ke pada jam puncak pagi

Tabel 7. Komposisi moda perjalanan hubung ke pada jam puncak pagi

\begin{tabular}{ccccc}
\hline No & Moda & Jumlah & Prosentase & Komulatif \\
\hline 1 & Jalan Kaki & 18 & $90 \%$ & $90 \%$ \\
2 & Angkot & 1 & $5 \%$ & $95 \%$ \\
3 & Sepeda Motor & 1 & $5 \%$ & $100 \%$ \\
4 & Mobil & 0 & $0 \%$ & $100 \%$ \\
\hline \multicolumn{5}{c}{20} \\
\hline
\end{tabular}

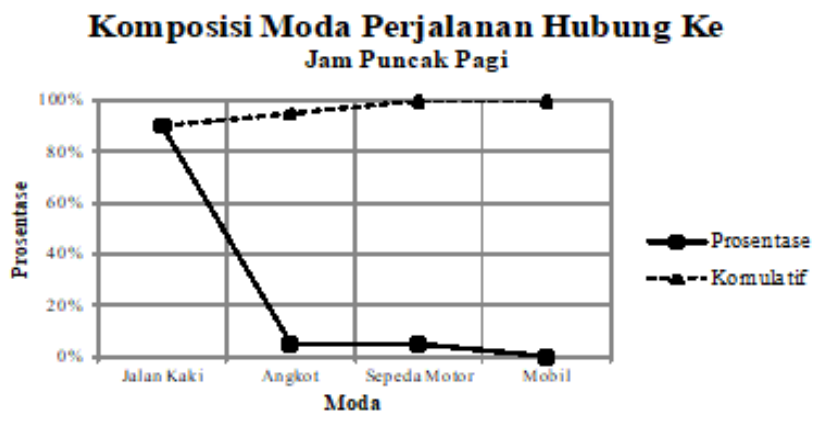

Gambar 7. Komposisi moda perjalanan hubung ke pada jam puncak pagi

Karakteristik perjalanan hubung dari Bis Trans Koetaradja untuk jarak perjalanan berkisar pada angka 0,0 - 1,0 km (95\%). Hasil survei menunjukkan bahwa moda perjalanan hubung dari seluruhnya pejalan kaki (100\%). Keseluruhan data karakterisitk disampaikan pada Tabel 8-9, dan Gambar 8-9.

Tabel 8. Komposisi jarak perjalanan hubung dari pada jam puncak pagi

\begin{tabular}{ccccc}
\hline No & Jarak & Jumlah & Prosentase & Komulatif \\
\hline 1 & $0,0-0,5 \mathrm{~km}$ & 13 & $65 \%$ & $65 \%$ \\
2 & $0,5-1,0 \mathrm{~km}$ & 6 & $30 \%$ & $95 \%$ \\
3 & $1,0-1,5 \mathrm{~km}$ & 1 & $5 \%$ & $100 \%$ \\
4 & $1,5-2,0 \mathrm{~km}$ & 0 & $0 \%$ & $100 \%$ \\
5 & $2,0-3,0 \mathrm{~km}$ & 0 & $0 \%$ & $100 \%$ \\
\hline \multicolumn{7}{c}{} & 20 & $100 \%$ & \\
\hline
\end{tabular}

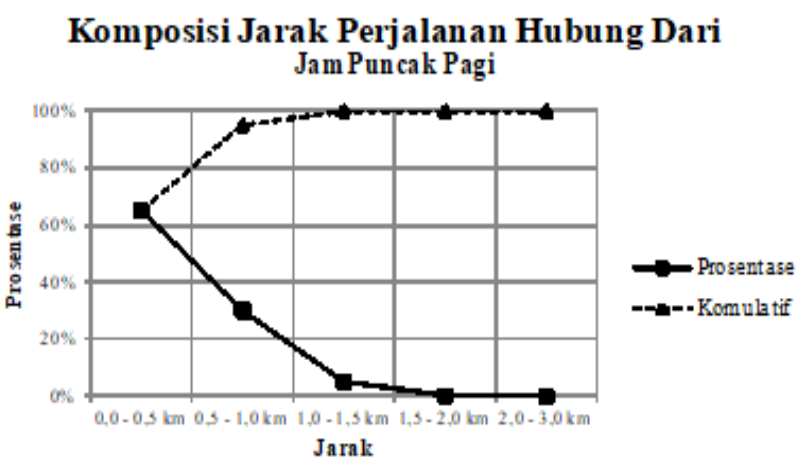

Gambar 8. Komposisi jarak perjalanan hubung dari pada jam puncak pagi

Tabel 9. Komposisi penggunaan moda perjalanan hubung dari pada jam puncak pagi

\begin{tabular}{|c|c|c|c|c|}
\hline No & Moda & Jumlah & Prosentase & Komulatif \\
\hline 1 & Jalan Kaki & 20 & $100 \%$ & $100 \%$ \\
\hline 2 & Angkot & 0 & $0 \%$ & $100 \%$ \\
\hline 3 & Sepeda Motor & 0 & $0 \%$ & $100 \%$ \\
\hline \multirow[t]{2}{*}{4} & Mobil & 0 & $0 \%$ & $100 \%$ \\
\hline & & 20 & $100 \%$ & \\
\hline
\end{tabular}

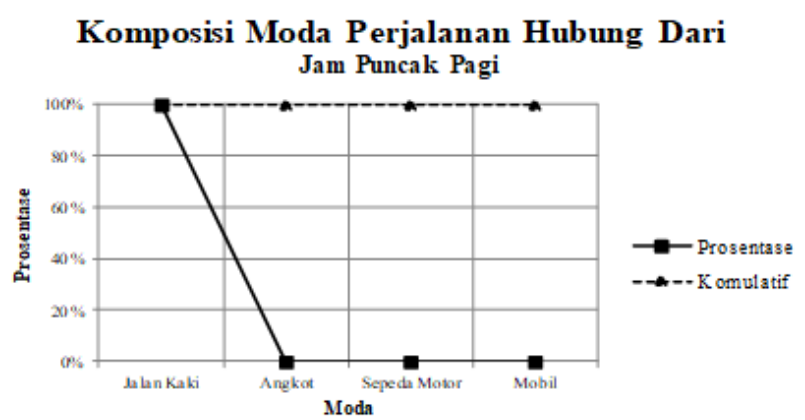

Gambar 9. Komposisi penggunaan moda perjalanan hubung dari pada jam puncak pagi

Karakteristik pada Jam Puncak Siang

Karakteristik utama pelaku perjalanan pada jam puncak siang untuk komposisi jenis kelamin adalah wanita 64\% dan laki-laki 36\%. Komposisi profesi pelaku didominasi oleh mahasiswa \& pelajar (65\%), pegawai negri \& pegawai swasta (25\%). Data Karaktersitik disampaikan pada Tabel 10, dan Tabel 11, sertta Gambar 10 dan Gambar 11.

Tabel 10. Komposisi jenis kelamin pelaku perjalanan pada jam puncak siang

\begin{tabular}{ccccc}
\hline No & Maksud & Jumlah & Prosentase & Komulatif \\
\hline 1 & Wanita & 47 & $64 \%$ & $64 \%$ \\
2 & Laki-Laki & 27 & $36 \%$ & $100 \%$ \\
\hline \multicolumn{5}{c}{74} \\
\hline
\end{tabular}




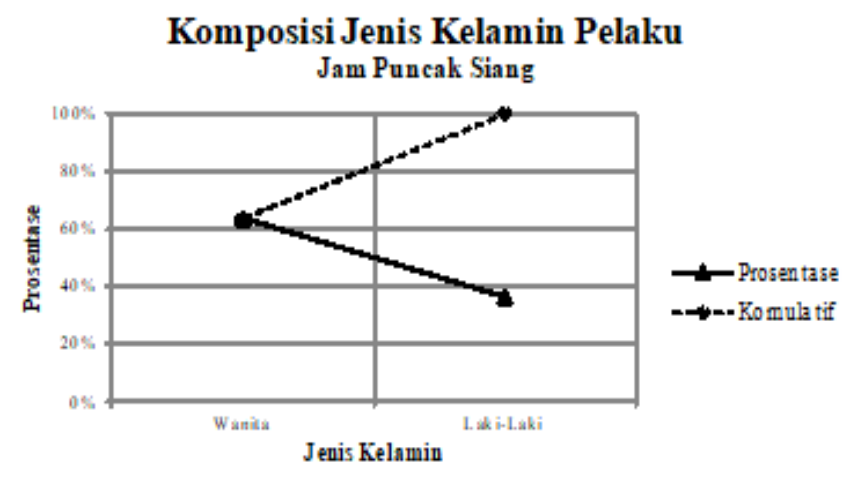

Gambar 10. Komposisi jenis kelamin pelaku perjalanan pada jam puncak siang

Tabel 11. Komposisi profesi pelaku perjalanan pada jam puncak siang

\begin{tabular}{ccccc}
\multicolumn{5}{c}{ puncak siang } \\
\hline No & Maksud & Jumlah & Prosentase & Komulatif \\
\hline 1 & Mahasiswa & 38 & $51 \%$ & $51 \%$ \\
2 & Pelajar & 10 & $14 \%$ & $65 \%$ \\
3 & Swasta & 10 & $14 \%$ & $78 \%$ \\
4 & Pegawai & 8 & $11 \%$ & $89 \%$ \\
5 & PNS & 5 & $7 \%$ & $96 \%$ \\
6 & IRT & 3 & $4 \%$ & $100 \%$ \\
\hline \multicolumn{5}{c}{}
\end{tabular}

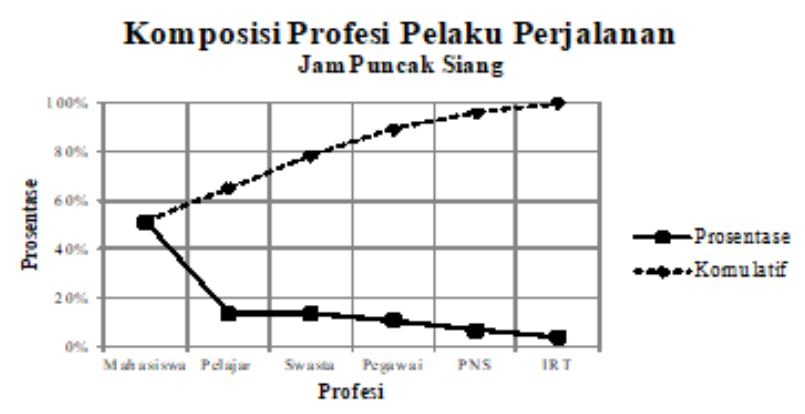

Gambar 11. Komposisi profesi pelaku perjalanan pada jam puncak siang

Karakteristik perilaku perjalanan utama untuk maksud perjalanan didominasi oleh perjalanan kuliah \& sekolah (41\%), serta perjalanan pulang (30\%). Penggunaan moda sebelum beralih ke Bis Koetaradja didominasi oleh sepeda motor (38\%), angkot mikrobis (35\%), serta becak (27\%). Keseluruhan data karakteritik maksud perjalanan dan moda sebelum beralih disampaikan pada Tabel 12, dan Tabel 13, serat Gambar 12, dan Gambar 13.
Tabel 12. Komposisi maksud perjalanan pada jam puncak siang

\begin{tabular}{ccccc}
\hline No & Maksud & Jumlah & Prosentase & Komulatif \\
\hline 1 & Kuliah/Sekolah & 30 & $41 \%$ & $41 \%$ \\
2 & Pulang & 22 & $30 \%$ & $70 \%$ \\
3 & Bekerja & 10 & $14 \%$ & $84 \%$ \\
4 & Belanja & 5 & $7 \%$ & $91 \%$ \\
5 & Lain-Lain & 7 & $9 \%$ & $100 \%$ \\
\hline \multicolumn{5}{c}{} \\
\hline
\end{tabular}

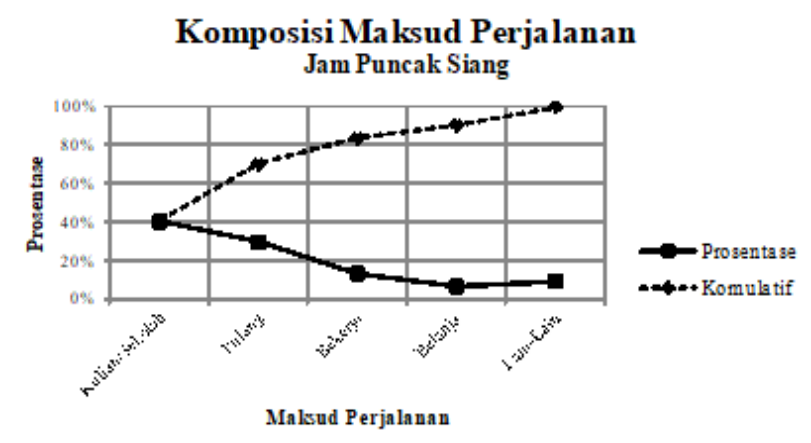

Gambar 12. Komposisi maksud perjalanan pada jam puncak siang

Tabel 13. Komposisi penggunaan moda sebelum beralih pada jam puncak siang

\begin{tabular}{ccccc}
\hline No & M oda & Jumlah & Prosentase & Komulatif \\
\hline 1 & Sepeda Motor & 28 & $38 \%$ & $38 \%$ \\
2 & A ngkot & 26 & $35 \%$ & $73 \%$ \\
3 & Becak & 20 & $27 \%$ & $100 \%$ \\
4 & Mobil & 0 & $0 \%$ & $100 \%$ \\
\hline \multicolumn{5}{c}{} \\
\hline
\end{tabular}

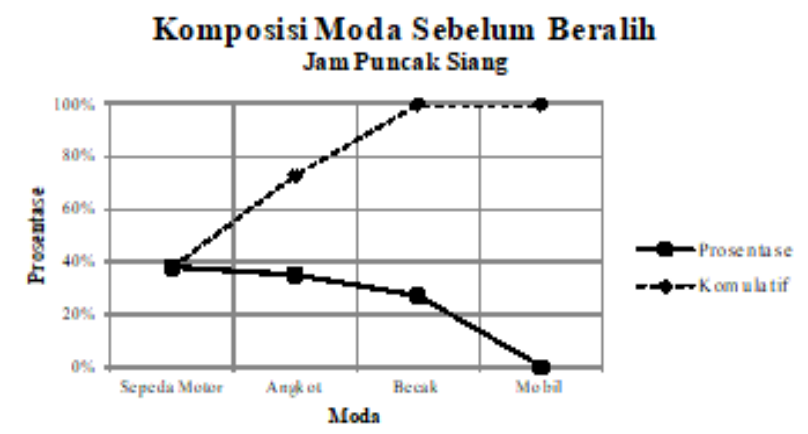

Gambar 13. Komposisi penggunaan moda sebelum beralih pada jam puncak siang

Karakteristik perilaku perjalanan hubung ke Bis Trans Koetaradja untuk jarak perjalanan hubung ke berada pada kisaran 0,0 - 2,0 km sebesar 86\%. Penggunaan moda perjalanan hubung ke didominasi oleh jalan kaki (85\%), serta sepeda motor (11\%). Data keseluruhan disampaikan pada Tabel 14-15, serta Gambar 14-15. 
Tabel 14. Komposisi jarak perjalanan hubung ke pada jam puncak siang

\begin{tabular}{ccccc}
\hline No & Jarak & Jumlah & Prosentase & Komulatif \\
\hline 1 & $0,0-0,5 \mathrm{~km}$ & 32 & $43 \%$ & $43 \%$ \\
2 & $0,5-1,0 \mathrm{~km}$ & 16 & $22 \%$ & $65 \%$ \\
3 & $1,0-1,5 \mathrm{~km}$ & 4 & $5 \%$ & $70 \%$ \\
4 & $1,5-2,0 \mathrm{~km}$ & 12 & $16 \%$ & $86 \%$ \\
5 & $2,0-3,0 \mathrm{~km}$ & 4 & $5 \%$ & $92 \%$ \\
6 & $3,0-5,0 \mathrm{~km}$ & 4 & $5 \%$ & $97 \%$ \\
7 & $>5,0 \mathrm{~km}$ & 2 & $3 \%$ & $100 \%$ \\
\hline \multicolumn{5}{c}{} \\
\hline
\end{tabular}

Komposisi Jarak Perjalanan Hubung Ke Jam Puncak Sing

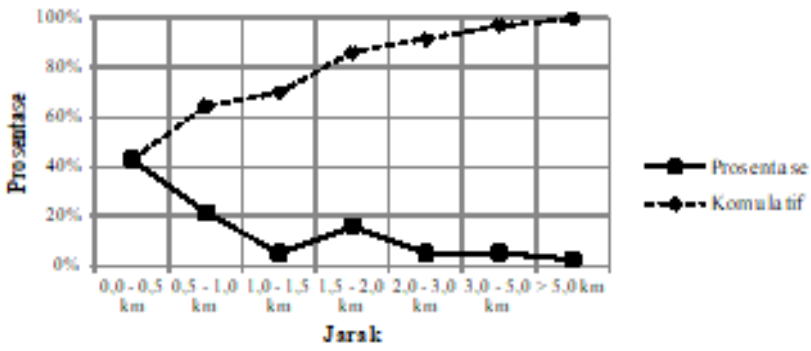

Gambar 14. Komposisi jarak perjalanan hubung ke pada jam puncak siang

Tabel 15. Komposisi penggunaan moda perjalanan hubung ke pada jam puncak siang

\begin{tabular}{ccccc}
\hline No & Moda & Jumlah & Prosentase & Komulatif \\
\hline 1 & Jalan Kaki & 63 & $85 \%$ & $85 \%$ \\
2 & Sepeda Motor & 8 & $11 \%$ & $96 \%$ \\
3 & Becak & 3 & $4 \%$ & $100 \%$ \\
4 & Angkot & 0 & $0 \%$ & $100 \%$ \\
\hline \multicolumn{5}{r}{} \\
\hline
\end{tabular}

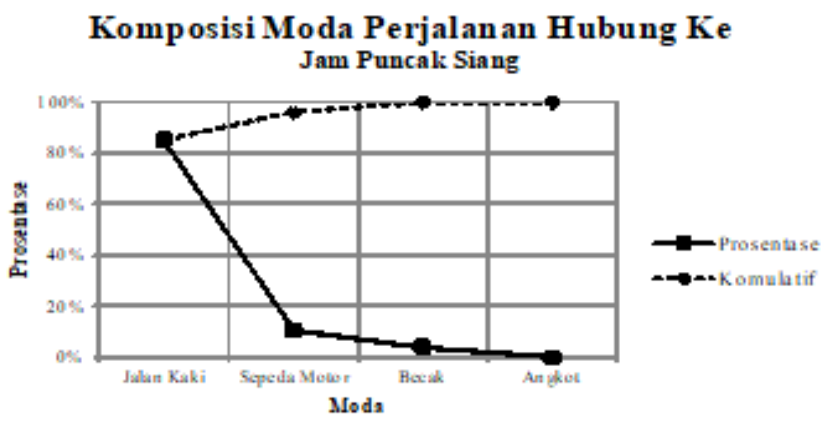

Gambar 15. Komposisi penggunaan moda perjalanan hubung ke pada jam puncak siang

Karakterisitk perjalanan hubung dari Bis Trans Koetaradja untuk jarak perjalanan hubung dari berada pada kisaran 0,0 - 1,5 km sebanyak 77\%. Penggunaan moda hubung dari didominasi oleh jalan kaki (99\%) dan sepeda motor (1\%). Keseluruhan data karakteristik disampaikan pada Tabel 16-17, serta Gambar 16-17.
Tabel 16. Komposisi jarak perjalanan hubung dari pada jam puncak siang

\begin{tabular}{ccccc}
\hline No & Jaralk & Jumlh & Prosentase & Komulatif \\
\hline 1 & $0,0-0,5 \mathrm{~km}$ & 31 & $42 \%$ & $42 \%$ \\
2 & $0,5-1,0 \mathrm{~km}$ & 23 & $31 \%$ & $73 \%$ \\
3 & $1,0-1,5 \mathrm{~km}$ & 3 & $4 \%$ & $77 \%$ \\
4 & $1,5-2,0 \mathrm{~km}$ & 12 & $16 \%$ & $93 \%$ \\
5 & $2,0-3,0 \mathrm{~km}$ & 3 & $4 \%$ & $97 \%$ \\
6 & $3,0-5,0 \mathrm{~km}$ & 2 & $3 \%$ & $100 \%$ \\
7 & $>5,0 \mathrm{~km}$ & 0 & $0 \%$ & $100 \%$ \\
\hline \multicolumn{5}{r}{} \\
\hline
\end{tabular}

\section{Komposisi Jarak Perjalanan Hubung Dari Jam Puncak Siang}

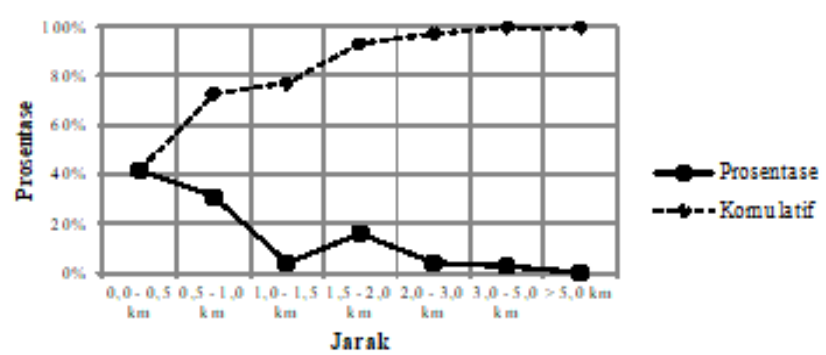

Gambar 16. Komposisi jarak perjalanan hubung dari pada jam puncak siang

Tabel 17. Komposisi penggunaan moda perjalanan hubung ke pada jam puncak siang

\begin{tabular}{ccccc}
\hline No & Moda & Jumlah & Prosentase & Ko mulatif \\
\hline 1 & Jalan Kaki & 73 & $99 \%$ & $99 \%$ \\
2 & Sepeda Motor & 1 & $1 \%$ & $100 \%$ \\
3 & Becak & 0 & $0 \%$ & $100 \%$ \\
4 & Angkot & 0 & $0 \%$ & $100 \%$ \\
\hline \multicolumn{5}{r}{} \\
\hline
\end{tabular}

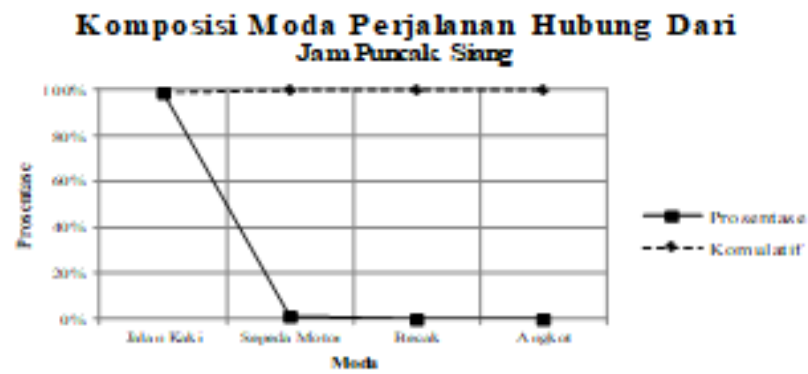

Gambar 17. Komposisi penggunaan moda perjalanan hubung ke pada jam puncak siang

\section{Sintesa Karakteristik}

Secara umum karakteristik pelaku dan perilaku perjalanan tergambar dari jumlah penumpang pada jam puncak pagi sangat sedikit - sekitar 10 orang, sedangkan pada jam puncak siang cukup banyak - sekitar 40-50 orang. Jenis kelamin penumpang didominanasi oleh wanita. Profesi penumpang didominasi oleh pegawai, pelajar dan mahasiswa. Maksud perjalanan didominasi oleh perjalanan 
bekerja, perjalanan kuliah dan perjalanan sekolah. Penggunaan moda sebelum beralih didominasi oleh sepeda motor dan angkot mikrobis. Perjalanan hubung ke secara umum mempunyai jarak pada kisaran 0-1,5 km, dengan moda berjalan kaki. Perjalanan hubung dari secara umum mempunyai jarak perjalanan pada kisaran 0-1 km, dengan moda moda berjalan kaki.

\section{Simpulan}

Dari hasil dan pembahasan dapat diambil beberapa kesimpulan sebagai berikut:

1. Volume penumpang Bis Trans Koetaradja Koridor 1 pada jam puncak pagi sangat sedikit, sekitar 10 orang sekali jalan; sedangkan volume penumpang pada jam puncak siang sekitar 40-50 orang sekali jalan.

2. Karakteristik penumpang Bis Trans Koetaradja Koridor 1 didominasi oleh penumpang wanita; dalam hal profesi didominasi oleh pegawai, mahasiswa dan pelajar.

3. Karakteristik perilaku perjalanan penumpang dalam hal maksud perjalanan didominasi oleh perjalanan bekerja, perjalanan kuliah dan perjalanan sekolah; sedangkan dalam hal pemakaian moda sebelum berpindah didominasi oleh moda angkot mikrobis dan moda sepeda motor.

4. Karakteristik perjalanan hubung ke dalam hal jarak didominasi oleh kisaran panjang 0-1,5 km, sedangkan penggunaan moda didominasi oleh moda jalan kaki.

5. Karakteristik perjalanan hubung dari dalam hal jarak didominsi oleh kisaran panjang 0-1 km, sedangkan penggunaan moda didominasi oleh jalan kaki.

6. Secara umum jarak perjalanan hubung ke lebih panjang sedikit dari pada jarak perjalanan hubung dari.

\section{Daftar Pustaka}

[1] Fakhurrazy, "Transportasi Masal di Banda Aceh". Tugas Kuliah. Jurusan Teknik Sipil, Universitas Syah Kuala, Banda Aceh, 2016.

[2] H. Suprayitno \& V.A. Upa, "Mamminasata BRT User Trip Characteristics for the Design of Demand Modelling Method for a New BRT Line”, IPTEK, The Journal for Technology and Science, Vol. 27, Issue. 3, December 2016, pp: 47-52.

[3] H. Suprayitno \& V.A. Upa, "Special Conventional Transport Model for a New BRT Line Passenger Demand Prediction”, JTSS - Journal of Technology and Social Science, Vol. 1, Issue 3, 2017, pp: 10-18.

[4] V.A. Upa, "Perhitungan Jumlah Permintaan Potensial Bus Rapid Transit (BRT) Mamminasata Koridor 1 dengan menggunakan Special Conventional
Transport Model”, Tesis Magister, Jurusan Teknik Sipil. Institut Teknologi Sepuluh Nopember (ITS), Surabaya, 2017.

[5] A. Soimun, "Analisis Probabilitas Perpindahan Moda Pengguna Kendaraan Pribadi (Sepeda Motor dan Mobil) ke Kereta Api Commuter Surabaya Sidoarjo”, Tesis Magister, Departemen Teknik Sipil. Institut Teknologi Sepuluh Nopember (ITS), Surabaya, 2018.

[6] O.Z. Tamin, Perencanaan, Pemodelan \& Rekayasa Transportasi: Teori, Contoh Soal \& Aplikasi, Penerbit ITB, Bandung, 2008. 
